Crime, Histoire \& Sociétés / Crime, History \& Societies

Vol. 1, n² | 1997

Varia

\title{
Recent Writing on Stalin's Gulag : An Overview
}

John Keep

\section{(2) OpenEdition}

\section{Journals}

Electronic version

URL: https://journals.openedition.org/chs/1014

DOI: $10.4000 /$ chs. 1014

ISSN: 1663-4837

\section{Publisher}

Librairie Droz

\section{Printed version}

Date of publication: 1 June 1997

Number of pages: 91-112

ISSN: 1422-0857

\section{Electronic reference}

John Keep, "Recent Writing on Stalin's Gulag : An Overview", Crime, Histoire \& Sociétés / Crime, History \& Societies [Online], Vol. 1, n² | 1997, Online since 03 April 2009, connection on 22 March 2022. URL: http://journals.openedition.org/chs/1014 ; DOI: https://doi.org/10.4000/chs.1014

\section{(c) Droz}




\title{
Recent Writing on Stalin's Gulag: An Overview
}

\author{
John Keep
}

I.

ver twenty years have elapsed since publication in the West of Alexander Solzhenitsyn's epic «literary-historical investigation » into the Soviet penitentiary system under Stalin, when the term « Gulag Archipelago » entered into our common vocabulary. The work's appearance made public opinion more aware of the repressive nature of the Soviet regime, but among professional «sovietologists» its impact was less overwhelming. It did not immediately generate a wave of interest in this grim topic. Paradoxically, its vast scope and artistic qualities may even have had a deterrent effect: had not everything been said so persuasively that it should better be avoided by lesser mortals, especially if they had never been forced, as Solzhenitsyn had, to experience the system «from inside»?

In the United States in particular students of the Stalin era were polarized between adherents of the traditional view and so-called «revisionists». The former stressed the dictator's responsibility for the Great Terror and other repressive measures taken against Soviet citizens innocent of any fault; they sought to explain these phenomena in ideological and institutional terms and did not hide their abhorrence of such a massive perversion of judicial norms. They drew their evidence largely from first-hand accounts by survivors, supplemented by the limited official data that were then available: reports of Party meetings, newspapers, economic and demographic statistics. Their challengers claimed that personal narratives were tainted by subjectivity and so unreliable; that the Terror was best seen as a social process which owed more to input from below than to decisions by the central leadership, which had not in practice exercised such a close control over events as was generally supposed; that its scope was less than catastrophic; and that it was wrong to use politically loaded terms like « totalitarianism» or to speculate on Stalin's personal motives; to do so was to give comfort to the "cold warriors ".

Their critics responded with charges of naiveté and thought the worst offenders apologists for Stalinism. During the early 1980 s, as the debate proceeded, the protagonists moderated and refined their arguments; progress was made in interpreting statistical material, but no consensus was reached. The truth, it seemed, lay buried in Soviet archives, and at the time these seemed likely to remain for ever inaccessible to independent researchers.

In 1987-1988, with the advent of glasnost' under Gorbachev, a new era began to dawn. Dissident or critical writers in the USSR broached historical topics that had hitherto been strictly taboo, such as the Nazi-Soviet pact or the costs of forced industrialization. KGB functionaries responded to the threat by destroying incriminating 
records, as they had done during the Khrushchev era, but they also launched a public relations drive in an effort to repair the security services' tarnished image. A.N. Yakovlev, the leading advocate of reform in Gorbachev's inner circle, stood for an honest disclosure of past and present abuses. He chaired a Politburo commission to investigate crimes committed «between the 1930s and the early 1950s» (a deliberately anodyne appellation!) and to rehabilitate the victims. Documents were published on several well-known cases fabricated by the NKVD on Stalin's orders to destroy groups of alleged «oppositionists». Hundreds of thousands of former Gulag inmates, or in most cases their descendants, received from the judicial authorities a notification that the verdicts against the accused had been annulled since no offence had been committed. In August 1990 Gorbachev signed a decree restoring the civil rights of all those who had suffered without cause under Stalin. Some fortunate survivors, in Moscow and elsewhere, were granted privileged access to food supplies and health care. In general, however, compensation was on a derisory scale and no proceedings were taken against the perpetrators of these crimes.

Meanwhile progressive press organs like the weeklies Argumenty $i$ fakty and Ogonek featured readers' letters, memoirs and other material on the Stalinist «repressions» (a vague but convenient term). In several localities civic organizations sprang up. Especially significant were branches of the «Memorial » society. Its members sought to honour the dead by erecting monuments at the sites of former prison camps, holding documentary exhibitions, and generally collecting as much relevant information as possible. Excavations undertaken in several places, notably Kuropaty in Belarus, uncovered mass graves containing thousands of human remains. These activities have continued since the Soviet Union's collapse in 1991, despite adverse conditions. Funds are scarcer than ever, due to the economic malaise, and officials often less supportive than they should be. On the other hand archive access has been liberalized ${ }^{\mathrm{l}}$.

Public interest has likewise waned. Most citizens are preoccupied with their immediate needs. Many are nostalgic for a Soviet past that seemed to offer greater political stability and better material conditions. They are not in a mood to assume their moral responsibility by trying to come to terms with a past that now lies far distant. The few living Gulag survivors are in their eighties or nineties. Although practically every family in the land suffered to some degree from Stalin's terror, memories of it have been subsumed into those of World War II, which have consistently received far more media attention. People would like to forget all these associated horrors. As Sonia Margolina notes, « there is no social need for a differentiated analysis of history. Men and women living between deprivation and the mafia have no tomorrow to believe in. And whoever takes no thought for the morrow needs no yesterday $»^{2}$.

The uncertainties of the political situation in Yeltsin's Russia evoke fears that some future government might tighten censorship and reimpose restrictions on access to the archives. In this event documentary publications would once again

1 Very few researchers, however, have gained entry to the security services' archive (AFSBRF). The Russian Federation State Archive (GARF), the former TsGAOR, and the former Central Party Archive, now RTsKhIDNI, contain some material, such as reports by the security authorities to the political leadership. Documents from APRF (the President's Archive) are being gradually de-classified and transferred to the public domain; some of them have been published.

Neue Zürcher Zeitung, 15 January 1997, p. 43. 
have to focus on harmless patriotic themes and the people's historical consciousness, which over the past decade has been slowly facing up to reality, would be forcibly re-mythologized. This ugly prospect makes it urgent to evaluate what has been achieved hitherto, by the labours of historians in the former Soviet Union and the West, sometimes in mutually beneficial co-operation. How do their fresh insights enlarge our understanding of Stalin's Gulag? (For reasons of space we shall confine ourselves to this topic, although it is clearly only part of a larger question, the Stalinist regime's pseudo-judicial policy in general - i.e. state terrorism.)

\section{II.}

Let us first construct a typology of the recent literature ${ }^{3}$. In the Russian Federation - books and articles appearing in Ukraine and other ex-Soviet republics cannot be treated here - some works are apparently the fruit of a partnership between security officials and «independent» scholars - a practice that, given Soviet antecedents, should come as no surprise. The first volume of a history of the «organs of state security » during World War II (1995) bears the FSB's imprimatur, whereas V. Nekrasov's history of the Interior ministry (NKVD/MVD) is apparently an unofficial study ${ }^{4}$. Neither of these concentrates on the Gulag, but a compendium of relevant legislation appeared in 1993, and the military historian O.F. Suvenirov has contributed a brief study of the para-judicial organ that settled the fate of nearly 50000 victims of the Great Terror ${ }^{3}$. In 1993 there appeared a collection of essays written «on the basis of investigatory materials and Gulag camp reports" and a three-volume collection on «repressed $»$ nationalities ${ }^{6}$. Yakovlev himself has followed up a book on the rehabilitation process (1991) with some general reflections under the title $A$ Bitter $\mathrm{Cup}^{7}$. Another prolific writer, N.F. Bugai, heads an academic study group on the deported minorities; one of his documentary collections is available in English translation ${ }^{8}$. In general the «special settlers» (exiles) have attracted more attention, notably from V.N. Zemskov, than the inmates of camps and colonies - a point we shall return to later.

Significantly, some of the works just noted appeared in provincial centres, and it is to such publications that we must turn for studies of particular regions. Those put out by «Memorial » branches are usually printed in small editions and rarely reach Western libraries ${ }^{9}$. The best work has been done on western Siberia, by the well-

3 Russian-language joumals are abbreviated as follows: Ist. = Istochnik, (suplement to Rodina); $N N I$ = Novaia i noveishaia istoriia; $O A=$ Otechestvennye arkhivy; $O I=$ Otechestvennaia istoriia; $V I=$ Voprosy istorii.

4 Yampolsky et al. (1995); Nekrasov (1995).

s Sbornik zakonodatel'nykh i normativnykh aktov o repressiiakh $i$ reabilitatsii zhertv politicheskoi repressii, Moscow, 1993; Suvenirov (1995).

- Po materialam sledstvennykh del i lagernykh otchetov Gulaga, Moscow 1993; Tak eto bylo : natsional'nye repressii v SSSR 1919-1952 gg. : repressirovannye narody segodnia, Moscow, 1993, 3 vols., comp. S. Alieva.

7 Yakovlev et al. (1991, 1994); also his essay (1993) and especially his report on the treatment of repatriates after 1944 (1996).

- Bugai (1995), cf his articles in Voprosy istorii, 1990, 7 and Otechestvennaia istoriia, 1992, 4.

- Belenkin et al. (n.d.). 
known agrarian historian V.P. Danilov and an associate. Their three-volume study of special settlers in this region, published in 1992-4, runs to over 900 pages; it reproduces the relevant orders (also those of local provenance!) and subordinates' reports on their fulfilment ${ }^{10}$. In the Far East, where the NKVD ran the notoriously homicidal Dalstroy camps, I.G. Striuchenko and his colleagues in Vladivostok are editing a multi-volume work to remind people of «forgotten names», while O.P. Yelantsev has written two articles on railway-building projects constructed by forced labourers in the region ${ }^{11}$.

Moving back west to the Urals, the fate of the so-called «kulaks » (actually, peasant householders of all kinds and their families !) who were deported there in the early 1930s is analysed in a monograph by T.I. Slavko and a volume of essays edited (locally, in Yekaterinburg) by V.I. Pervukhina ${ }^{12}$. Further to the north-west lay the multiple camp complexes situated between Kotlas and Vorkuta (Pechora valley, Komi ASSR), about which much can be learned from two all too brief articles, one by N.A. Morozov and M.B. Rogachev and the other by V.Ya. Shashkov, as well as the memoirs of A.N. Kaneva ${ }^{13}$. For the "repression » of the non-Russian minorities of the middle Volga, the English-speaking reader now has an excellent study by $\mathrm{K}$. Sanukov of the "purge " in the Mari republic, while the Kazan' historian A.L. Litvin deals expertly, in several articles, with the Tatars ${ }^{14}$.

The list could be extended, but enough has been said to show that local historians are producing rich fruit. Such works are often more explicit, and more humane in approach, than studies of the Gulag phenomenon in its entirety. The same applies of course to memoirs, such as those by the writer L.E. Razgon, Nepridumannoe (1987/8), now available in major Western languages ${ }^{15}$. This is of necessity a genre in decline, but the well-known accounts published earlier, notably those by $E$. Ginzburg or V. Shalamov, have not lost their relevance. So far as is known, none of the thousands of officials, guards and so on who ran the penal system has given us his side of the story - for reasons that are obvious.

In the West historiography of the Gulag has recently entered a qualitatively new phase with the appearance of R. Stettner's comprehensive study ${ }^{16}$. This synthesizes the vast amount of material previously published in the West as well as much of the post-Soviet literature. Its author has not, however, had access to the archival sources on which the latter studies are based and omits the special settlers. He also foregoes sociological analysis of the convict population, but offers, as the title indicates, a thorough account of their conditions and the way the system worked. In an appendix Stettner reviews the "numbers controversy" which continues to rage among Anglo-Saxon historians, but without offering a definitive answer of his own. For

10 Danilov, Krasilnikov (1992), reviewed by I.Ye. Zelenin in Otechestvennaia istoriia, 1996, 5, p. 195198; cf. Kuznetsov's three-part collection of documents (1993); and the excellent collection of essays in French on one camp complex in this region: Brossat, Combe, Moukhine (1991).

1 Striuchenko et al. (1994); Yelantsev $(1992,1995)$.

12 Slavko (1995); Pervukhina (1994); there are also two useful articles by Plotnikov $(1994,1995)$.

13 Morozov, Rogachev (1995); Shashkov (1996); Kaneva (1991); on the topic Shashkov has written a dissertation and a book (Shashkov, 1993).

14 Sanukov (1996); Litvin (1994) and a paper for the ICCEES congress in Warsaw (1995), to be published shortly in English (Litvin, 1995).

15 Razgon (1991).

16 Stettner (1996). 
this the time is not yet ripe, since we lack the detailed information (still in FSB hands!) that could show how the figures on population, mortality etc., which Zemskov and two Western « revisionist » partners have put forward with such confidence, were obtained ${ }^{17}$. Also sceptical in this regard is $\mathrm{E}$. Bacon, who did use some archival sources for his book on the Gulag in World War $\mathrm{II}^{18}$; predictably this has been warmly welcomed by some historians, such as R. Conquest, but has encountered a cool reception from others. In 1996 Stephen Wheatcroft, for the revisionists, and Steven Rosefielde, for the traditionalists, dealt yet another round in their long drawn-out battle of statistical computations ${ }^{19}$. M. Jakobson has written a scholarly account of the way Stalin transformed the Soviet penal system, suppressing its early reformatory features ${ }^{20}$, while the journalist Adam Hochschild, a sensitive and thoughtful observer, has recorded impressions of a visit to the USSR in 1991 when he was able to inspect several Gulag sites and talk to former prisoners, Memorial activists and others ${ }^{21}$.

Anglo-American writers sometimes neglect scholarship in German, which is making a significant contribution. In addition to Stettner's book just mentioned, there is an important study by $S$. Karner of the fate of German prisoners of war ${ }^{22}$. They came under a different part of the security establishment, GUPVI, which was independent of GULag. Also relevant are the proceedings of a conference held at Mülheim (Ruhr) in 1995, due to appear shortly, at which the participants boldly sought to compare the Stalinist terror with that of the Nazis ${ }^{23}$. The field is growing exponentially as new documentation becomes available.

III.

We may now attempt to summarize what has been learned so far. Perhaps the most significant finding relates to the categorization of prisoners - although we have to remember that in a system that was inherently arbitrary it would be misleading to expect legalistic precision, so that there are exceptions to every generalization one makes. What might be called the "slave class» consisted of two major groups: a) inmates of forced-labour camps (ITL) and colonies (ITK) and b) exiles, i.e. settlers or «special settlers». The camps were of three degrees of ascending severity; the colonies were designed for short-term offenders (in principle, up to three years) and theoretically life there was more bearable, although in practice the distinction might not matter much. As Razgon remarks, «l'essentiel n'est pas le règlement mais le geôlier ${ }^{24}$, so that in bad periods colony inmates, too, suffered high mortality due to starvation and overwork. There were several other categories of camp: those for

17 Getty, Rittersporn, Zemskov (1993), and ensuing correspondence.

18 Bacon (1994), which develops earlier studies in Soviet Studies, 1992, 44, p. 1069-1086 and Revue d'études comparatives Est-Ouest, 1992, p. 229-246.

19 Rosefielde (1996); Wheatcroft (1996).

20 Jakobson (1993).

21 Hochschild (1994).

22 Karner (1995); Bonwetsch (1993).

23 For a preliminary account: Dahlmann, Linden, Scheide (1995).

24 Razgon (1991, p. 117). 
forced labour (katorga) from 1943 onward, and the «special camps » set up in 1948; furthermore the «filtration camps » for repatriates with their subordinate «points ". Such «points» really correspond to the English term «camp»; these were grouped in larger entities best referred to as «complexes». Several sources refer to the existence of execution camps, but these units were apparently as a rule concealed within a particular sub-system and did not comprise a category of their own. Apart from all this, there were people in jail or en route from one installation to another.

The inmates of all the foregoing may be said to have formed the Gulag's «inner core», and the exiles its «outer rim»-but not in a territorial sense, for people in the two main categories co-existed side by side, often working on the same projects even alongside nominally «free» labourers. We are thus really dealing with the lowermost tiers in a social hierarchy in which everyone lived under some degree of coercion. On completing their sentence, camp inmates might well be recategorized as settlers. This meant that they were no longer held behind barbed wire but could live in the same or another region under NKVD control, with any family members who chose to share their fate, while working at jobs designated by the authorities, who restricted their movements and continued to watch them closely; their earnings were liable to deductions. The exiles' lot was much harsher than that of their predecessors under the tsar. For any misdemeanour they might find themselves sent back to an ITL. Moreover, in 1948 it was ruled that settlers (and that automatically meant prisoners, too) should be kept in distant regions indefinitely. On the other hand, the geographical centre of gravity of the settler population seems to have shifted southward, to less inhospitable parts of the country, in the post-war years.

Political offenders were convicted under one paragraph or another of the notorious catch-all Article 58 of the criminal code. Briefly, the «normal» course of events was for them to be arrested (either on a denunciation or as a member of some group deemed suspect and swept up en masse, or else simply to fulfil the local NKVD/MVD agency's quota of arrests). They were held in pre-trial custody, interrogated (perhaps using «illicit methods», i.e. torture) to obtain a confession, and then brought before a quasi-judicial tribunal such as a local troyka or the NKVD/MVD's Special Board, which would pass sentence: to execution (VMN = «the highest measure of punishment»), to a term in jail or camp (more rarely, in exile), usually followed by one of exile, or to some other penalty; there were very few acquittals. But just as some people were detained without being formally arrested, so others might be punished without being formally convicted. In this makebelieve world a sentence of «ten years without right of correspondence» was a codeword for execution. It is accordingly not easy to estimate the numbers killed or confined in various installations.

The cases of common-law offenders were generally heard before regular civil courts. These normally sentenced culprits to a term of forced labour (especially if their conduct seemed politically undesirable), but might be content to order them to serve a term «without deprivation of liberty» at their normal place of employment on reduced pay. The latter do not concern us here. The former and the "politicals " came within the orbit of the NKVD/MVD. Security officials decided where they were to be sent and, in effect, whether they survived or perished. Custodial terms could be extended at their whim. Appeals to the judicial authorities stood no chance of being heeded unless the police concurred, for the procurators, supposedly the guardians of legality, had no independence. 
Possessed of absolute power, Gulag administrators at all levels had every incentive to exploit the convicts' labour to the full in order to meet the production targets they were allocated, but precious little incentive to care for their charges' wellbeing. Guards were forbidden to socialize with the zeks (as prisoners called themselves). They were trained to look on them contemptuously as human flotsam, as anonymous «labour power" (rabsila). This attitude alone requires one to be cautious about accepting these officials' own estimates of the size of the convict population. Zemskov has recently claimed that they had no reason either to inflate or minimize the numbers ${ }^{25}$. This is a dubious assertion; for if in the command economy industrial managers regularly falsified data on stocks, output and the like, as is now generally acknowledged, why should not their NKVD/MVD counterparts - fearful, ambitious and lacking administrative skills - have behaved likewise? Many of them were, after all, so-called pridurki: prisoners, in the main common-law offenders with a criminal background, who had been co-opted to assist with the office work a job that enabled them to escape physically demanding and dangerous labour « outside» on construction projects. Razgon describes eloquently the cheating that went on over the allocation of jobs, rations and the like ${ }^{26}$. The more conscientious bureaucrats were better at recording the movement of vehicles or materials than those of human beings. Typically, when reporting the transport of people eastward, they would pedantically note the number of railway waggons used, and so conceal the loss of prisoners en route.

Curiously, there was no central agency to co-ordinate statistics on the number of prisoners reported by subordinates. This is another reason why doubts persist about the veracity of the totals supplied in 1953/4 by the MVD's First Special Department to the post-Stalin Party leadership when the latter requested it after Beria's elimination. The original draft (December 1953) included 282926 persons convicted for anti-state offences under articles in the code other than Article 58, who were not mentioned in the better-known February 1954 document signed by the security chief, Kruglov, and two other senior officials. This stated that, over the entire period since 1921, the security organs had sentenced 642,980 individuals to death, 2369220 to camps (and colonies?) or jails, and 765180 to (ordinary) exile 27 . This document was not made public until the Gorbachev era, and the figures are clearly under-stated. Wheatcroft proceeds from an assumption of about 1 million put to death in the late 1930s, but reproduces without criticism the figures for those despatched to the Gulag ${ }^{28}$.

In 1992 V.P. Popov came up with other figures for sentences by the security authorities alone (from 1929) that were higher for those sent to camps or jails ( 2530 654 ) but lower for ordinary exiles $(362041)^{29}$. He also gave figures for civil court sentences, but only for a few years, 1940 and $1945-53^{30}$. These show that, during

25 Zemskov (1995a).

26 Razgon (1991, p. 121). Note especially the case of Colonel Vypolzov at Ustvymlag (Ukhta), who used prison labour to make art objects, not registered in the camp's output, which where used to buy superior officials' goodwill.

27 Zemskov (1989).

28 Wheatcroft $(1996$, p. 1331, 1336).

29 Popov (1992).

30 Ibid., 23. A Ministry of Justice report for civil court sentences in 1952-1953 gives other figures, 1548834 and 1183483 (respectively 59,7 and $45,6 \%$ higher), but these may include some sentences not involving deprivation of liberty; Werth, Moullec (1994, p. 52-54). 
these ten years, a further 5949370 persons lost their liberty. This gives a total of 8 842065 , to which one would need to add an estimate of those given judicial sentences over the remaining 25 peace-time and 3 war-time years. One may agree with Bacon's educated guess that between 1934 and 1947 the net intake into the camps was 8.1 million, and if colonies are included $121 / 4$ million. For the whole period to Stalin's death he suggests a figure of over 18 million $^{31}$. This estimate is by no means excessive. We know from Popoy's list that in 1948-53 the civil courts and the security authorities respectively passed custodial sentences on 3275336 plus 294583 individuals. These figures apparently do not include that proportion of repatriates and repressed ethnic minorities who, as actual or potential security threats, landed up in camps as distinct from settlements.

Moreover, there is no reason to exclude from the final tally the several million exiles in the special settlements, about whom more will be said later. In January 1953 there were more of them than there were convicts in the «inner Gulag»: 2,75 million against 2,47 million. Finally, there were several hundred thousand in jail and the prisoners of war: about 3 million Germans plus half a million or so Japanese and several hundred thousand from other Axis states. Most historians exclude the latter from the reckoning, but their lot was broadly similar to that of «natives".

The Gulag was a universe continually on the move as prisoners were transferred from one facility to another. The official statistics do not neatly list the influx into the system (as individuals were sentenced) and the efflux through deaths, releases and so on. There are rather mysterious entries each year for «transfers» which the more benign commentators believe may just refer to inmates sent to and from work assignments. Others, more sceptically disposed, think they may cover deaths not registered as such, whether deliberately contrived or not. Such problems of interpretation could be settled only by examining at first hand the data submitted by individual sub-divisions and camp complexes, on which the First Special Department's totals were presumably based. Unfortunately such material, if it still exists, has not yet been made available. Thanks to the labours of Bacon, Stettner and others, we do at least know the titles of these administrative units and roughly what they did; some incomplete data on the population they controlled have seen the light.

The figures for the Gulag population on 1 January of successive years, though of interest in themselves, do not tell us how many entered or left the system during any given year. Wheatcroft helps us by adding figures for «mid-year» ( 1 July?) as well ${ }^{32}$. From these data (whose accuracy, to repeat, is far from assured) it is clear that the initial influx into the camps, mainly peasant «kulaks» and ex-«bourgeois», during the First Five-year plan era was followed by another in the late 1930s, the years of the Terror, and another after 1944/5. There was a slight decline (2,3 per cent) between January 1936 and 1937, but then expansion continued more rapidly, so that when the Germans invaded the camps alone held 1458000 persons, an increase of 77,6 per cent on January 1937 (820 881). This is of course no guide to the actual number sent to camps during the "purges ", since many died there - and some were released. These new entrants probably numbered about 4 million, although Zemskov acknowledges less than 1 million (1936-40), over 200000 of

\footnotetext{
31 Bacon (1994, p. 27, 36).

32 Wheatcroft (1996, p. 1328-1329).
} 
whom entered in $1937^{33}$. The third great influx, after war-time losses, brought the figure up from around 1,5 million in January 1945 - roughly half in camps and half in colonies - to the already cited 2,47 million $(1,72+0,74$ million $)$ in January 1953 , shortly before Stalin's death forestalled yet another increase at the expense of suspect «cosmopolitans» (mainly Jews). This is still a dark era in the history of the Gulag, as of other aspects of Soviet life, although the murk is slowly clearing in regard to, say, the post-war famine.

Much more work needs to be done on mortality rates in camps and colonies before we can arrive at plausible figures. One cannot really expect precise recordkeeping of deaths by officials who, as Stettner reminds us, systematically mutilated the corpses of deceased prisoners in order to prevent inmates escaping by feigning death ${ }^{34}$. By keeping «dead souls» on strength an administrator could hope to receive more rations (but also higher work norms). Zemskov claims «absolutely precise information » from an archival source that only 1083829 ITL inmates died over the twenty-year period beginning 1 January $1934^{35}$. No composite figure was found for ITK inmates but, extrapolating from their average ratio to camp inmates, he puts their mortality at «not more than 0,5 million», and adds in a figure of 86582 for deaths in prison (1939-44,1946-51) to arrive at a total estimate of 1,6-1,7 million custodial deaths for 1935-53. The arithmetic of this computation is not beyond reproach $^{36}$. In his joint article with two Western revisionist historians the estimate is raised to «a little more than 2.3 million », including settlers, but to 1940 only, when the worst was of course yet to come. The authors take refuge in evasion: «we have some reason to believe that the new numbers... are likely to bring us within a much narrower range of error than the estimates proposed by the majority of authors... $)^{37}$. Perhaps: but we know that losses were nevertheless catastrophically high, especially during and just after the war.

In an earlier article (1991) Zemskov himself acknowledged that «in 1942 and 1945 the statistics for the loss ( $\left.u b y l^{\prime}\right)$ of prisoners in camps are incomplete" . Here he gave annual figures for ITL deaths (to 1947 only) as in column 1 of Table 1.

These are clearly understated. They probably exclude prisoners in transit, inmates of filtration camps and other categories as yet unascertained. From these figures the mortality rate can be reckoned as in column 2 (they are a little different if one takes the annual average of inmates, but this increases the margin of error). A.N. Dugin has put the death rate in 1942 and 1943 at 22.7 and 22.8 per cent respectively, which is probably nearer the truth; Bacon has shown that in 1942, in camps working for the forestry department (ULLP), 34 per cent of those "lost" died, whereas in that for railway construction (GULZhDS) the rate was below 15 per cent; in the Dalstroy camps it was 19 per cent (round figures) ${ }^{38}$. Wheatcroft offers a maximum and minimum range (col. 3 in Table 1), including in the former those who «disappeared in transit» or escaped without being recaptured. Rosefielde

\footnotetext{
33 Zemskov (1995a, p. 110)

34 Stettner (1996, p. 283).

35 Zemskov (1995a, p. 119).

36 The ratio of colony to camp inmates $1935-1938$, which he oddly calls 'approximately twice as few', is actually, on his data, $41.78 \%$.

37 Getty et al. (1993).

38 Bacon (1994, p. 110).
} 
Table 1: Mortality in ITL, 1934-1947

\begin{tabular}{|l|c|c|c|}
\hline Year & $\begin{array}{l}\text { col. 1 } \\
\%\end{array}$ & $\begin{array}{l}\text { col. } 2 \\
\%\end{array}$ & $\begin{array}{l}\text { col. } 3 \\
\%\end{array}$ \\
\hline 1934 & 26295 & 5,15 & $4-11$ \\
1935 & 28328 & 3,93 & $4-7$ \\
1936 & 20595 & 2,45 & $3-7$ \\
1937 & 25376 & 3,09 & $3-6$ \\
1938 & 90546 & 9,09 & $8-12$ \\
1939 & 50502 & 3,83 & 4 \\
1940 & 46665 & 3,47 & $3-8$ \\
1941 & 100997 & 6,73 & $21-11$ \\
1942 & 248877 & 17,58 & $20-24$ \\
1943 & 166967 & 16,97 & $9-11$ \\
1944 & 60948 & 9,18 & $7-13$ \\
1945 & 43848 & 6,13 & $3-4$ \\
1947 & 18154 & 2,48 & $4-9$ \\
\hline
\end{tabular}

Sources: Zemskov (1991, p. 16-17). The source is not identified or dated, but its location in TsGAOR (now GARF) suggests that it is from the security services' report cited (by number only, without provenance) in fn. 29 of the Getty, Rittersporn, Zemskov (1993) article. Col. 3: Wheatcroft (1996, p. 1339; slightly different on p. 1329).

claims to have shown that the figures advanced by Zemskov and associates are internally inconsistent, although it is hard to accept his methodology ${ }^{39}$. He apparently adheres to an earlier estimate of an average camp mortality rate of 10 per cent per annum, and holds that 2.8 million died in detention in 1937-9 alone. The debate could be resolved only if we had new information from the papers of subordinate Gulag organs. The Tatarstan local archives contain data on the number sent to camps in certain years, but not about the losses within them ${ }^{40}$. It is clear that some regions, like Kolyma, were worse than others, and that political offenders were treated more harshly than common-law offenders.

How large was the proportion in each category? Scattered information suggests that roughly one-quarter to one-third were «politicals », but the ratio varied over the years, increasing spectacularly after 1944 and then falling again. We need to be careful about taking the official categories at face value. Some of those not indicted under Article 58 committed offences that were indirectly the result of the regime's repressive policies and would not normally be considered criminal, as when peasant women stole stalks of grain from the collective fields to feed their starving children ${ }^{41}$.

39 Rosefielde multiplies the number of sentences to camp and prison by the number of years to be served, and this by an average of Zemskov's and Wheatcroft's mortality rates; this yields a figure that is only half as great as that reported by the MVD in 1954 (Rosefielde, 1996, p. 968, table 2). This could imply that the latter data are arbitrary or that the sentencing data are understated. The latter hypothesis seems more persuasive.

40 Litvin (1994).

41 This point is well made by Graziosi (1992) where she puts the proportion of 'politicals' in 1946 as high as $59.2 \%$ but accepts Zemskov's figure of $30 \%$ for the post-war years in general. Cf. Getty et al. (1993, p. 1022, fn.19), who cite a note on a file to the effect that 36 per cent of those sentenced "on cases of the security police" were common-law offenders. 
One could, for example, be sentenced for committing an offence described by the rubbery formula "socially dangerous (harmful) act», which meant more or less whatever non-conformist behaviour the local authorities were keen to suppress at the time. Zemskov and associates, who seek to minimize the number of political as against common-law offenders, claim that over the twenty years 1933-53 (omitting 1934) only about 8.4 per cent of sentences, whether by the courts or by extra-judicial bodies, were rendered for alleged political offences ${ }^{42}$. They even claim that in 19378 , «when many believe the terror was mounting» (sic!), the share of «politicals » in the camps declined - but this decline, if indeed it occurred, can be explained by the fact that so many of those convicted were simply shot. In short, the nature of the charge in an accused's record is not a reliable guide as to the reason why he or she was repressed, and should not be taken too seriously by researchers. They should rather proceed from the assumption, difficult as it may be for outsiders to grasp, that the documentation in an individual case is fraudulent unless proved otherwise. Stalin's USSR was a society in which the criminals at the top determined who should be deemed guilty of what, and the job of court and police officials was to identify them, so filling their quotas. (Some, to their credit, resisted - and paid the penalty).

IV.

The newly accessible archives make it possible to attempt a sociological analysis of the Gulag population, but we cannot take this line of investigation here. Of all the criteria employed (age, gender, class and so on) that for ethnic allegiance is of greatest interest to the non-specialist. In what follows we shall be concerned mainly with the exiles, otherwise known as «special (or labour) settlers». In the early years these were predominantly Russians or other eastern Slavs - and by social origin peasants. The recent studies of the Urals and north Russia provide graphic evidence of the way these «kulaks» were treated. Nation-wide the first wave (1930-1) is thought to have numbered at least 1.8 million, family members included. It is now clear that, since local officials were given little advance warning of the influx, even the most benign of them could do little to alleviate the newcomers' lot. Deported from their native regions en masse and in great haste, without proper provision for the journey, many died en route. In 1930-1 alone 571000 such deportees arrived in the Urals. OGPU officials in Sverdlovsk reported (March 1931) that they were short of food and protective clothing essential to survive the harsh climate; those with ready money found nothing to buy; they had to do unfamiliar work in logging and were set impossibly high norms; local Party cadres were subjecting alleged laggards to cruel punishment (e.g., making them dig what they were told would be their graves). All this prompted a revolt, hitherto unknown to historians, which was brutally suppressed ${ }^{43}$.

Shashkov, a scholar in Murmansk, tells us that by January 1933 the northern region had been required to accommodate 301000 deportees (two-thirds of them by September 1930). He expresses sympathy for the victims - «humiliated, barefoot, hungry and cold»-but seems more concerned to hail their subsequent achieve-

42

Getty et al. (1993, p. 1034).

43 Plotnikov (1995). 
ments in boosting output: sowing potatoes, building up herds of cattle and so on ${ }^{44}$. This is a characteristic line for a post-Soviet historian to take. So, too, is a reluctance even to estimate what the mortality rate may have been. According to Zemskov and others; a remarkably large number of exiled peasants managed to escape, evade recapture, and reach home, where they were often made unwelcome by fellow villagers who had meanwhile taken over their property ${ }^{45}$.

In 1933 the peasant settlers were joined by common-law offenders, after Stalin ordered the country's overcrowded jails to be cleared, and in 1935-6 the process began of shifting to the interior masses of non-Russians whose presence in the border regions made them seem a liability should war break out. The first such group appears to have been Poles living on the western frontier, who were moved to Kazakhstan ${ }^{46}$. Another comprised Karelian Finns (and Finns generally). The regime took the threat of Fenno-Ugrian nationalism seriously (or pretended to do so) and this served as the rationale for the severe repression meted out inter alia to the Mari (Cheremis) people on the Volga ${ }^{47}$. At the other end of the country, in the Soviet Far East, no less than 172000 Koreans were rounded up and deported to Central Asia. Already en route they suffered much hardship; as in the case of the «kulaks », no proper arrangements had been made to receive them; and, although they had done nothing wrong, their status subsequently deteriorated until they came to be treated as "enemies of the people ${ }^{48}$. At the outset of this operation, which served as a dress rehearsal for others better known in the West, 3000 Koreans were arrested as political suspects and presumably sent to the «inner Gulag», along with 8000 Chinese. This proportion was relatively modest by comparison with the fate of Poles and others in the territories annexed in September 1939, in accordance with the terms of the Nazi-Soviet pact.

V.S. Parsadanova, the first Russian scholar to study this tragic episode, stated that 1.2 million people were deported, in several waves, and that 82 per cent of them became «special settlers», of whom 16 per cent died (presumably within the first two years) ${ }^{49}$. Wheatcroft states that 1.5 million were deported, of whom 0.6 million were Poles ${ }^{50}$. Several thousand officers and other former members of elite groups («class enemies») were taken to three internment camps. The "Katyn affair» is no longer the state secret that it was for so many years. In 1992 investigators came across one of Stalin's «special folders » revealing that the massacre was carried out on an express order by the Politburo dated 5 March 1940. The total number put to death by the NKVD was a greater than previously supposed: $21857^{51}$.

\footnotetext{
44 Shashkov (1996).

45 Fitzpatrick (1994).

46. Ivanov (1996, p. 164), offers a figure of 110000 , which seems rather high.

47 Gelb (1993); Sanukov (1996).

48 Bugai $(1992,1994)$. A «White Book» on this affair was published in 1992 by V.A. Li and E.E. Kim.

49 Parsadanova (1989).

so Wheatcroft $(1996$, p. 1344).

51 This figure is made up as follows : 4421 in Katyn forest, Smolensk province: 3820 in Starobelsk camp near Kharkov; 6311 in Ostashkovo camp, Kalinin province; 7305 in other camps and prisons. The job was supervised by an NKVD troyka consisting of Merkulov, Kobulov and Bashtakov. (Sekretnye dokumenty iz osobykh papok', VI, 1993, 1, p. 19-22). For an English translation: Matlock (1993). The «special folders " were kept separate from other official papers and made known only to successive Soviet leaders when they took over (in Khrushchev's case, in 1959).
} 
Many Jews resident in the annexed territories made their way eastward, voluntarily or otherwise, in 1939-41, which enabled some of them to escape the Nazi Holocaust. Whether this was Stalin's intention is unclear. Ukrainian and Belarusian deportees also seem to have fared better than Poles, but their lot was far from pleasant. They were distrusted and a proportion of them, as yet undetermined, ended their days in the Gulag. The same was true of inhabitants of northern Bukovina and Moldova (Bessarabia), seized from Romania in 1940. When the Baltic states fell into Stalin's grasp, they, too, were "sovietized» and in June 1941, on the eve of the German invasion, at least 16000 Lithuanians trod the path of exile ${ }^{52}$. Emigré sources put the minimum number at 34000 , plus 10000 Estonians and 15000 Latvians ${ }^{53}$. According to Zemskov, a total of 25586 Balts were exiled to settlements, where, as he puts it, "their numbers significantly diminished due mainly to an excess of deaths over births ». How many were shot or sent to camps he does not say. The figures for Baltic camp inmates on 1 January 1941 was 8896, and four years later 8129, but much happened in the interim and the post-war influx had yet to begin $^{54}$.

Since Zemskov wrote, a 1988 report to the Politburo «Yakovlev commission » by the KGB chief of the day, V.M. Chebrikov, has seen the light which gives data on arrests and deportations from all the western territories before and after the war as follows:

Table 2: KGB Data on Arrests and Deportations from Annexed Territories, 1941-1952

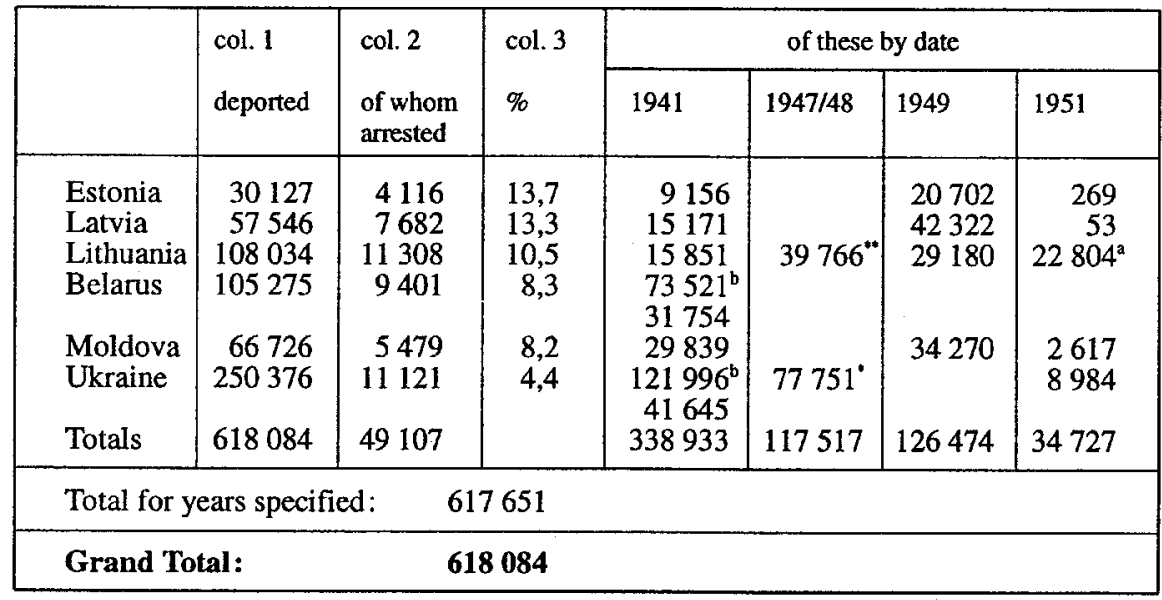

*1950-2 * 1947

- $1940 \quad * * 1948$

Source: Meropriiatiia po vyseleniiu iavlialis' chezvychainoi meroi, Istochnik, 1996, 1, p. 137-138.

Chebrikov stated that those arrested after the war were sent to camps for terms of five to eight years, followed by twenty years' exile - evidently without judicial

\footnotetext{
52 Izvestiia TsK KPSS (1990, 10, p. 129-139).

53 Misiunas, Taagepera (1983, p. 41).

54 Zemskov (1993).
} 
proceedings - and that family members were exiled for twenty years. He did not mention the 1940 shootings, presumably because they were still «top secret», and a check shows that his totals for the various years he mentioned come to 617651 , slightly less than the grand total given.

Returning to 1941 , when the Germans invaded, some inmates of camps in the western regions were shot while others had to trek east on a forced march that cost the lives of an estimated 10 per cent ${ }^{55}$. Stalin now had to change his policy toward Poles in the USSR. An amnesty was granted (12 August 1941), at which time, according to official data, there were 389382 Polish citizens in the country, of whom 120 962 (31,1 per cent) were in prison, camp or exile and 243106 (62.4 per cent) in « special settlements »; a further 25314 were held as prisoners of war $^{56}$. Of these 341 were excluded from the amnesty; 76100 combatants $^{57}$, with 43755 dependants, were allowed to leave via Iran to fight on in the Anders Army, while 36510 were enrolled in the Polish forces set up on Soviet soil. Beria's figure for deaths in 19413 is only 11516 and not credible.

As the fortunes of war changed after Stalingrad, the settlements, which like the rest of the Gulag had suffered heavy population losses, began to fill up again as entire ethnic minorities, arbitrarily categorized as disloyal, were punished by deportation eastward. The Soviet Germans, from the dissolved Volga German ASSR and other parts of the country, had been sent there already in 1941. According to Chebrikov (1988), they numbered 815000 , although other sources suggest that there were more than 1 million of them. The next big batch comprised the north Caucasian peoples: Chechens, Ingush, Karachai and Balkars, arrested en masse in the winter of 1944. According to a 1990 study the original target figure was in the region of 320000 , but was then raised to 460000 - and then over-fulfilled! We now have day-to-day figures for the numbers of Chechens and Ingush (only) loaded into railway waggons, which add up to 478479 ; by September 1944 this had risen to 496000 , perhaps because Red Army soldiers of these nationalities, who were arrested separately, were included ${ }^{58}$.

They were followed in May 1944 by the Crimean Tatars, who numbered 191044 ; at least this is the figure reported (to Beria, presumably) by the two NKVD generals responsible for the operation. They stated smugly, «no excesses of any kind took place» - as if the action had not itself been one great excess! Nearly 6000 Tatars were arrested as «anti-Soviet elements» and presumably shot or sent to camps. One wonders whether the proportion was comparable among the other Oriental groups. We also hear of a 5000 -strong «special contingent» (presumably not the same as that just mentioned), and the gross figure of those sent east is given in the source as 180014 - which may still be too low ${ }^{59}$.

ss J.T. Gross in Sword (1991, p. 50 ff.).

36 Beria to Stalin, 1 May 1944, in Bugai (1991, p. 153).

57 This figure is given as 119855 by Taranova (1993), as cited by Wheatcroft (1996, p. 1345).

s8 Kokurin (1993, p. 102).

59 Bugai (1991, p. 152-153). Sachka (in Osteuropa, 1988, 11, p. A512-516) put the figure at 191,088 and the total deported at 228543 . This includes local Armenian, Greek and other residents, who comprised some one-third of the peninsula's population. In September 1944 the chief official in charge of settlers gave the number deported from Crimea, and still alive then, at 225000 : Kokurin (1993, p. 102). In 1990, Zemskov put the number of Crimean Tatars who arrived at their destinations at 183155 ; this may be too high and not allow for losses on the way, which V. Tolz estimates at 5 per 
Also understated, it seems, are figures reported by the KGB in 1988 for all the Oriental groups as follows:

Table 3: KGB Data on Deported Oriental Groups, 1944

\begin{tabular}{|c|c|c|c|}
\hline $\begin{array}{l}\text { North Caucasians: } \\
\text { Kalmyks } \\
\text { Meskhetian Turks } \\
\text { Crimean Tatars }\end{array}$ & $\begin{array}{l}\text { Chechens } \\
\text { Ingush } \\
\text { Balkar } \\
\text { Karachai }\end{array}$ & & $\begin{array}{r}387229 \\
91250 \\
37103 \\
70095 \\
93139^{\mathrm{a}} \\
90000^{\prime} \\
190000\end{array}$ \\
\hline Total: & & at least & 958816 \\
\hline
\end{tabular}

- The (Buddhist) Kalmyks lived on the steppe between the Volga and the Caucasus: the Meskhetian Turks were mainly located in Georgia ${ }^{60}$.

That these data were compiled casually is clear from the fact that the figure for Crimean Tatars is rounded off by 1044 from that reproduced by Bugai. Chebrikov seems to have been reacting in haste to pressure by reformist elements in the Baltic republic Communist parties, and his purpose was just to arrive at a grand total of deportees for 1940-52, which he gave as «about 2,3 million people» (not the 1,6 million which result from his computations).

Zemskov and Popov have estimated the gross post-war increase of exile population at over 600000 . The chief groups were those just mentioned from the western territories, for there was considerable resistance here to the reimposition of Soviet rule. By 1 January 1951 there were 75646 Balts in camps and 20507 in colonies. To this figure must be added about two-thirds as many in settlements, for the latter are known to have held 172362 Balts two years later. They were located mainly in Siberia. About 28 per cent of these Baltic settlers were children, most of them born in captivity ${ }^{61}$.

The MGB was interested in the adult settlers' ethnic make-up and worked out data for 1 January 1953 which show that, taken together, the 139957 Balts comprised 6,9 per cent of the total. Germans (exclusive of prisoners of war) were the largest group and numbered 1224931 (44,5\%); north Caucasians stood at 498452 $(18,1 \%)$, and Tatars, Greeks and others from the Crimea $204698(7.4 \%)$. Other significant groups comprised Kalmyks (3,0\%), Meskhetian Turks $(1,8 \%)$, Moldavians $(1,3 \%)$ and Armenians $(0,6 \%)$. Curiously, there were still 36000 Poles from the first batch deported in 1936, or their descendants. Far more numerous were Ukrainian anti-Communists, classified as «OUNovtsy» or as «Banderites» or «Melnikovites» (after two guerilla leaders), at $175063(6,4 \%)$. The mainly Russian «Vlasovites» - i.e. supporters of the Russian Liberation Army (ROA) - were only

cent ('New Information...', Report on the USSR, 1991, 17, p. 19.). Zemskov (1995a, p. 118) has since claimed that only $0.13 \%$ died en route among the 151720 sent to Uzbekistan. (1990).

61 Zemskov (1993, p. 5-9). 
a third as large $(56746,2,1 \%)$; most of these men will have been shot or sent to camps $^{62}$.

Given the merciless spirit of the times, one can comprehend why harsh treatment was meted out to these men, who had collaborated with the German invaders, if only (in most cases) under duress. But the Stalinist regime was itself culpable in failing to distinguish properly between active enemies of the system - traitors or war criminals who had perpetrated massacres in the occupied areas - and the great mass of Soviet citizens who had fallen under German rule. These included Red Army soldiers captured by the enemy and civilians deported as Ostarbeiter. Only 4 per cent of Soviet prisoners of war joined units formed under Axis auspices. Nevertheless even those who had languished in Nazi concentration camps, or had fled to join Resistance movements in occupied Europe, were officially regarded as « exposed to enemy influence» and thus as potentially treacherous; repression was extended even to members of their families.

In 1990 Zemskov put the number of those repatriated at 4,2 million. More recently he has offered a higher figure: 5352963 (to January 1946 only) ${ }^{63}$. Of these 1153405 were «internally displaced persons » who, not having left Soviet territory, were technically not «repatriates ». Of the latter, 1,5 million were armed forces personnel and the rest civilians; there was an almost exactly equal number of Russians and Ukrainians. 1996 saw publication of an official report which a commission under Yakovlev had submitted to President Yeltsin ${ }^{64}$. This gave figures compatible with Zemskov's: by December 1946, 5,4 million people had been repatriated (among them the «internally displaced $»$ ?), including 1,8 million prisoners of war. As regards their subsequent fate, Yakovlev's data are preferable to Zemskov's. Some 1230000 men were returned to the armed forces, of whom most were placed in a reserve under the Defence ministry and were employed on mine clearance or construction work - later some were sent on to the Gulag (a new detail!). Also new is a figure for those who were convicted: 994270 , of whom 157593 were shot - by military tribunals alone. Those whose lives were spared became forced labourers. They included a 600000 -man «special contingent» which toiled under much the same conditions as other zeks.

As for those - men in the ranks and civilians - who, after passing through the network of filtration points and camps, were allowed to go home, they remained under police surveillance, suffered discrimination over jobs, housing and the like, and were especially prone to be denounced as politically unreliable by vindictive neighbours. Yakovlev shows that it was often the local authorities who pressed for harsher measures to be taken against the unfortunate repatriates, whose situation deteriorated after 1948. The military, to their credit, tried to intervene on their behalf with the MVD/MGB but to little avail so long as Stalin lived. Not until 1955 were some men amnestied or had their sentences reduced. The next year a commission under Marshal Zhukov discovered that since 1945 «no less than 1.5 million repatriated prisoners of war, the overwhelming majority of them innocent, had gone through a machine of terror that yielded nothing to the Gulag ${ }^{65}$.

\footnotetext{
62 Zemskov, in Argumenty i fakty, 1989, 39, p. 8.

63 Zemskov (1995b, 5, p. 9-10).

64 Yakovlev et al. (1996).

65 lbid., (p. 108).
} 
Perhaps the oddest feature of this mind-boggling injustice was that the Soviet authorities treated their own people worse than foreign prisoners of war. This was presumably because the latter, if they survived, were expected to return one day to their homelands. As S. Karner remarks, "a comparative study is urgently required of the Gulag, GUPVI and the German internment camps for prisoners of war " ${ }^{66}$. This task cannot be tackled here; suffice it to say that on both sides of the line there was crass neglect and maltreatment, especially in the early years, but that later conditions improved - more so on the Soviet side, which at least did not apply genocidal policies in their regard. Rations in Soviet camps were on a par with those of civilians outside the wire. V.B. Konasov, in the most thorough inquiry yet made into this subject, leaves open the question how many prisoners died - German sources suggest about 1 out of 3 million - and points out that the figures were manipulated by the NKVD/MVD ${ }^{67}$. Wheatcroft has shown that the so-called "mobilized Germans ", who were picked up in eastern Germany in 1945-6 and sent to work in the USSR, suffered an exceptionally severe fate ${ }^{68}$.

Post-Soviet writings contain some evocative memoirs, notably in S.S. Vilensky's collection of material by and about women prisoners ${ }^{69}$. How far this modifies the picture we already have of physical conditions in the Gulag or victims' survival strategies cannot be considered here. Another subject that deserves extended treatment elsewhere is the contribution which forced labour made to the USSR's economic growth in the 1930 s and to post-war reconstruction. It was clearly greater in some sectors (e.g. gold-mining) than others. There has been some discussion as to the relative importance of economic motivations in establishing and maintaining the Gulag, as distinct from the aim of bolstering the regime's security by ridding Soviet society of elements deemed undesirable. To my mind this is not a very propitious avenue of inquiry. Certainly, the location of camps and settlements was dictated by economic considerations, and the officials who ran them were, as pointed out above, primarily concerned with boosting output. Yet the reasons why so many people were "put inside» were non-economic. They had to do rather with the totalitarian essence of a regime ideologically committed to building a social utopia, one that scorned as «bourgeois » considerations of legality or morality, and considered it «scientifically correct» to repress anyone who dissented or was deemed likely to do so. The security police and judiciary were cogs in what Zelenin calls « a state machine built especially for organizing forced labour and destroying people on a mass scale». This does not mean that the machine functioned efficiently, and we should not forget the few brave, honest officials who tried to mitigate the victims' lot or even refused to carry out inhuman orders.

Resistance within the Gulag is another rewarding theme. It gathered force after 1948 , notably among certain non-Russian groups as well as hardened criminals. This was a consequence partly of improved conditions (the end of the «Great Hunger»), and ranged from petty insubordination to the great strikes of 1953-1954 ${ }^{70}$.

66 Dahlmann et al. (1995, p. 212). 
Writing on the Gulag, broadly speaking, has passed through three stages: descriptive, literary (Solzhenitsyn), and statistical. We need to integrate all these approaches and to place the knowledge gained since 1987-1988, which is mainly about administrative matters and the various cohorts within the custodial population, in a perspective inspired by humanistic thinking and respect for judicial norms. A juridical approach is the most promising, but moral considerations cannot be excluded. Whether they should determine the direction of scholarly research is perhaps a matter of opinion. It is not reprehensible for investigators to have a passionate desire to uncover historical truths and see justice done. Whether this is practicable is another question. It can be held that the state terrorism of the Stalin era does not fall within the scope of «crimes against humanity » as defined in international law and that such acts are no longer justiciable. On the other hand some form of atonement seems desirable: after all the system did not come to an end in 1953. One thinks of current experience in Germany, Albania, Ethiopia - or South Africa. Public apology by prominent sinners seems to have become a fashionable practice, and is to be welcomed as an acceptable substitute for legal proceedings that for some reason cannot be held. What court would hear a case brought against Beria and his acolytes - or for that matter against the operatives of the KGB or FSB ?

In Russia itself legal consciousness is poorly developed. There is neither any judicial mechanism capable of dealing with such matters nor a widespread public demand for retribution. On the contrary, even the victims' descendants display a remarkable readiness to «forgive and forget» which may owe something to the country's cultural and religious traditions as well as to the practical calculation that retribution would provoke further violence, and that it is therefore better to let sleeping dogs lie. Some citizens adhere to a concept of collective responsibility so broad as to rule out any accounting with the past: everyone had to compromise himself or herself under totalitarian conditions and so «we are all guilty up to a point». At the other extreme we have the brash ex-camp commandant of Ozerlag, Yevstigneev, who claims that all his actions were legal and for the good of his captives ${ }^{71}$.

Neither sentiment should obstruct the historians' efforts to identify the individuals who bore responsibility for crucial decisions and to evaluate their acts according to conventional criteria. Such mundane labours are an essential preliminary to any eventual stock-taking on a higher moral or judicial plane. This may take a generation or so to accomplish: one thinks of the taboo that for twenty years or so kept scholars from studying the Holocaust. The work done in recent years by our postSoviet colleagues is commendable in many respects. It has the virtues (and defects) of being written close to the sources. For understandable reasons these scholars tend to work up a particular body of archival information to which they have managed to gain access, without paying much attention to the context or drawing broad conclusions. Rarely do they refer to parallel work being done by colleagues, and even more rarely to the work of foreign specialists. Their isolation is partly due to the sheer practical difficulty of obtaining expensive books and journals published in the West, a problem that ought not to be insuperable. Partly, though, it is a matter of intellectual barriers. Many seem unduly sensitive to possible charges of injuring their

71 Combe (1991, p. $214 \mathrm{ff})$. 
country's international reputation and so exercise restraint when passing judgement. As noted, their studies concentrate on the settlers rather than ITL/ITK inmates, a somewhat less painful theme. Writers are not always sufficiently attentive to the problem of falsification of official material. Zemskov has yet to reveal the circumstances in which he began to publish hitherto top secret information from NKVD/MVD files - although he has told us that in 1989 he was appointed a member of a commission of historians investigating population losses ${ }^{72}$. He is openly hostile towards foreign critics of the Communist record and even of Russian «democrats» (his inverted commas!).

Western «revisionists» take a similar line. Both Rittersporn and Wheatcroft, the former more vehemently than the latter, see it as their duty to attack the position taken by anti-Communist stalwarts such as Conquest, allegedly in the cause of scholarly objectivity. The risk of sliding towards an apologetic stance, though less marked than it was, has not yet been wholly eliminated. This is perhaps more apparent in American than European (especially German) scholarship. However, lapses can occur anywhere. The respected $\mathrm{N}$. Werth was perhaps a little unwise to claim,

Table 4: Security Police Data on Size of Custodial Population. (1 January)

\begin{tabular}{|c|c|c|c|c|}
\hline Year & $\begin{array}{l}\text { col. } 1 \\
\text { camps }\end{array}$ & $\begin{array}{l}\text { col. } 2 \\
\text { colonies }\end{array}$ & $\begin{array}{l}\text { col. } 3 \\
\text { settlers }\end{array}$ & $\begin{array}{l}\text { col. } 4 \\
\text { prisons }\end{array}$ \\
\hline $\begin{array}{l}1932 \\
1933 \\
1934 \\
1935 \\
1936 \\
1937 \\
1938 \\
1939 \\
1940 \\
1941 \\
1942 \\
1943 \\
1944 \\
1945 \\
1946 \\
1947 \\
1948 \\
1949 \\
1950 \\
1951 \\
1952 \\
1953\end{array}$ & $\begin{array}{r}269000 \\
334000 \\
510307 \\
725483 \\
839406 \\
820881 \\
996367 \\
1317195 \\
1344408 \\
1500524 \\
1415596 \\
983974 \\
663594 \\
715506 \\
746871^{c} \\
808839 \\
1108057 \\
1216361 \\
1416300 \\
1533767 \\
1711202 \\
1727970\end{array}$ & $\begin{array}{c}? \\
212000 \\
240259 \\
457088 \\
375488 \\
885203^{\mathrm{a}} \\
355243 \\
315584 \\
429205 \\
360447 \\
500208 \\
516225 \\
745171 \\
956224 \\
912794 \\
1091478 \\
1140324 \\
1145051 \\
994379 \\
793312 \\
740554\end{array}$ & $\begin{array}{c}1317022 \\
142084 \\
1072546 \\
973693 \\
1017133 \\
916787 \\
877651 \\
938552 \\
997513 \\
960133^{b} \\
? \\
? \\
? \\
? \\
? \\
? \\
? \\
2300323 \\
? \\
? \\
? \\
2753356\end{array}$ & $\begin{array}{c}? \\
? \\
? \\
? \\
? \\
545000 \\
? \\
350538 \\
190266 \\
487739 \\
277992 \\
235313 \\
155213 \\
279969 \\
261500 \\
306163 \\
275850 \\
? \\
? \\
? \\
? \\
?\end{array}$ \\
\hline
\end{tabular}

- Including 548417 prison inmates (10 Feb. 1938); cf. Getty et al., (1993, p. 1019, fn. 9) for a figure of 548756 prisoners in early 1938 .

b April.

c. or 600897 ?

Sources: Zemskov (1991) and other works; col. 1, lines 1-2 from Wheatcroft (1996, p. 1332). 
on the basis of Zemskov's revelations, that we at last have «les vrais chiffres » on the population of the Gulag ${ }^{73}$. Yes, the official data are clearly better than earlier outside estimates, but are they complete? They need critical scrutiny. We do not yet know the answers to many important questions, because the accounting system was chaotic and the figures lent themselves to manipulation. Bureaucratic as well as political motives led to the separate registration of various categories of prisoner. In judging the Stalinist system one has to beware of institutionalized mendacity and avoid leaping to conclusions. Scholars in this sensitive field need to be humble about the extent of current knowledge but ambitious in setting future goals.

\section{REFERENCES}

Bacon, E., The Gulag at War: Stalin's Forced Labour System in the Light of the Archives, London, 1994.

Belenkin, B. et al., (comps.), Bibliograficheskii ukazatel' izdanii obshchestva «Memoriala» 1988-1995, n.p., n.d.

Bonwetsch, B., Sowjetische Zwangsarbeiter vor und nach 1945: ein doppelter Leidensweg, Jahrbücher für Geschichte Osteuropas, 1993, 41, p. 532-546.

Brossat, A., Combe, S., Moukhine, L., Ozerlag, 1937-1964: le système du Goulag: traces perdues, mémoires réveillées d'un camp stalinien, Paris, 1991.

Bugai, N.F., Pravda o deportatsii chechenskogo i ingushskogo narodov, Voprosy istorii, 1990 , 7, p. 32-44.

Bugai, N.F., Ogruzheny $\mathrm{v}$ eshelony $\mathrm{i}$ otpravleny $\mathrm{k}$ mestam poselenii, L. Beria - I. Stalinu, Istochnik SSSR, 1991, 1.

Bugai, N.F., O vysylke koreitsev iz Dal'nevostochnogo kraia, Otechestvennaia istoriia, 1992, 6, p. 140-168.

Bugai, N.F., Vyselenie sovetskikh koreitsev s Dal'nego Vostoka, Voprosy istorii, 1994, 5, p. 141-148.

Bugai, N.F., From Beria to Stalin: In Accordance with Your Instructions, Moscow, 1995. Combe, S., S.K. Evstigneev, roi d'Ozerlag, in Brossat et al., 1991, p. $214 \mathrm{ff.}$.

Dahlmann, D., Linden, A., Scheide, C., Lager, Zwangsarbeit, Vertreibung und Deportation: Dimensionen der Massenvernichtung in der Sowjetunion und in Deutschland 1933-1945, Berliner Jahrbuch für osteurop. Geschichte, 1995, 2, p. 209-218.

Danilov, V.P., Krasilnikov, S.A., (eds.), Spetspereselentsy v Zapadnoi Sibiri, 1930 - vesna 1931 g.; vesna 1931 - nachalo 1933 g.; 1933 - 1938. Novosibirsk, 1992-1994.

Fitzpatrick, S., Stalin's Peasants: Resistance and Survival in the Russian Village after Collectivization, New York-Oxford, 1994.

Gelb, M., Karelian Fever: the Finnish Immigrant Community during Stalin's Parges, EuropeAsia Studies, 1993, 45, p. $1091-1116$.

Getty, J.A., Rittersporn, G.T., Zemskov, V.N., Victims of the Soviet Penal System in the Prewar Years: A First Approach on the Basis of Archival Evidence, American Historical Review, 1993, 98, p. 1017-1049.

Graziosi, A., The Great Strikes of 1953 in Soviet Labour Camps, Cahiers du monde russe et soviétique, 1992, 33, p. 419-446.

73 Werth (1993). 
Hochschild, A., The Unquiet Ghost: Russians Remember Stalin, New York, 1994.

Ivanov, N., Die Polen in der Ukraine, Osteuropa, 1996, 2.

Jakobson, M., Origins of the Gulag: The Soviet Prison Camp System, 1917-1934, Lexington KY, 1993.

Kaneva, A.N., UkhtPechLag, 1929-1938, Zven'ia, 1991, 1, p. 331-356.

Karner, S., Im Archipel GUPVI: Kriegsgefangenschaft und Internierung in der Sowjetunion, 1941-1956, Vienna-Munich, 1995.

Kokurin, A.I., Spetsposelentsy v SSSR v 1944 g., ili god bol'shogo pereseleniia, Otechestvennye arkhivy, 1993, 5.

Kokurin, A.I., Vosstanie v Steplage, mai - iiun' 1954 g., Otechestvennye arkhivy, 1994, 4, p. 33-81.

Konasov, V.B., Sud'by nemetskikh voennoplennykh v SSSR: diplomaticheskie, pravovye $i$ politicheskie aspekty problemy: ocherki i dokumenty, Vologda, 1996.

Kuznetsov, I.N., Znat' i pomnit': istoricheskoe issledovanie massovykh repressii i reabilitatsii zhertv terrora 30-kh gg., Tomsk, 1993.

Litvin, A.L., Preemniki VChK, ili nesostoiavshiisia grazhdanskii mir, Tatarstan, 1994, 11 ; 1994,$12 ; 1995,1-2$.

Litvin, A.L., Rossiiskaia istoriografiia Bol'shogo Terrora, ICCEES congress in Warsaw, 1995, (forthcoming).

Matlock, W. (Ed.), Katyn: Documents of Genocide, Warsaw, 1993.

Misiunas, R.J., Taagepera, R., The Baltic States: Years of Dependence, 1940-1980, London, 1983.

Morozov, N.A., Rogachev, M.B., GULag v Komi ASSR (20-e-50-e gg.), Otechestvennaia istoriia, 1995, 2, p. 182-187.

Nekrasov, V., Trinadtsat' zheleznykh narkomov: istoriia NKVD-MVD ot A.I. Rykova do N.A. Shchelokova, 1917-82, Moscow, 1995.

Parsadanova, V.S., Deportatsiia naseleniia iz Zapadnoi Ukrainy i Zapadnoi Belorossii v 19391941 gg., Novaia i noveishaia istoriia, 1989, 2, p. 26-44.

Pervukhina, V.I., (ed.), Raskulachennye spetspereselentsy na Urale, 1930-1936 gg., Yekaterinburg, 1994.

Plotnikov, I. Ye., O tempakh i formakh kollektivizatsii na Urale, Otechestvennaia istoriia, 1994,3, p. 77-91.

Plotnikov, I. Ye., Ssylka krest'ian na Ural v 1930-e gg.: dokumenty iz arkhivov, Otechestvennaia istoriia, 1995, 1, p. 160-179.

Popov, V.P., Gosudarstvennyi terror v Sovetskoi Rossii, 1923-1953: istochniki i ikh interpretatsii, Otechestvennye arkhivy, 1992, 2, p. 20-31.

Razgon, L.E., La vie sans lendemains, Paris, 1991.

Rosefielde, S., Stalinism in Post-Communist Perspective: New Evidence on Killings, Forced Labour and Economic Growth in the 1930s, Europe-Asia Studies, 1996, 48, p. 959-987.

Sanukov, K., Stalinist Terror in the Mari Republic: The Attack on «Finno-Ugrian Bourgeois Nationalism», Slavonic \& East European Review, 1996, 74, p. 658-682.

Shashkov, V. Ya., K voprosu o vyselenii raskulachennykh semei v Severnyi krai, 1930-1933 gg., Otechestvennaia istoriia, 1996, 1, p. 150-155.

Shashkov, V. Ya., Spetspereselentsy na Murmane: rol' spetspereselentsev v razvitii proizvoditel'nykh sil na Kol'skom poluostrove (1930-1936 gg.), Murmansk, 1993.

Slavko, T.I., Kulatskaia ssylka na Urale 1930-1936, Moscow, 1995. 
Stettner, R., «Archipel GULag»: Stalins Zwangslager - Terrorinstrument und Wirtschaftsgigant: Entstehung, Organisation und Funktion des sowjetischen Lagersystems 19281956, Paderborn, 1996.

Striuchenko, I.G. et al. (eds.), Zabytye imena: stat'i $i$ ocherki, fasc. 1, Vladivostok, 1994.

Suvenirov, O.F., Voennaia kollegiia Verkhovnogo Suda SSSR (1937-1938 gg.), Voprosy istorii, 1995, 4, p. 137-46.

Sword, K. (Ed.), The Soviet Takeover of the Polish Eastern Provinces, 1939-1941, London, 1991.

Vilensky, S.S., Dodnes' tiagoteet: istoriia moei sovremennitsy, Moscow, 1990.

Werth, N., «Goulag: les vrais chiffres», L'Histoire, 1993, 169, p. 38-51.

Werth, N., Moullec, G. (trs., eds.), Rapports secrets soviétiques: la société russe dans les documents confidentiels, 1921-1991: recueil de pièces d'archives de la documentation contemporaine, Paris, 1994.

Wheatcroft, S., The Scale and Nature of German and Soviet Repression and Mass Killings, 1930-1945, Europe-Asia Studies, 1996, 48, p. 1319-1353.

Yakovlev, A.N. et al., (eds.), Reabilitatsiia: politicheskie protsessy 30-50-kh gg., Moscow, 1991.

Yakovlev, A.N., Blutige Vergangenheit, Jahrbuch für Kommunismusforschung, 1993, 1, p. 226-248.

Yakovlev, A.N. et al., (eds.), Gor'kaia chasha, Yaroslavl, 1994.

Yakovlev, A.N., Sud'ba voennoplennykh i deportirovannykh grazhdan SSSR: materialy Komissii po reabilitatsii zhertv politicheskikh repressii, Novaia $i$ noveishaia istoriia, 1996, 2, p. 91-113.

Yampolsky, V.P. et al., (eds.), Organy gosudarstvennoi bezopasnosti v Velikoi Otechestvennoi voyne: sbornik dokumentov, tom 1: Nakanune, noiabr' 1938 -dekabr' 1940 g., Moscow, 1995.

Yelantsev, O.P., Iz istorii stroitel'stva zheleznoi dorogi Komsomol'sk-Sovetskaia Gavan', 1943-1951 gg., Otechestvennye arkhivy, 1995, 3, p. 90-99.

Yelantsev, O.P., Kto i kak stroil BAM v 30-e gody, Otechestvennye arkhivy, 1992, 5, p. 71-81.

Zemskov, V.N., Arkhipelag GULAG : glazami pisatelia i statistika, Argumenty i fakty, 1989, 45.

Zemskov, V.N., Gulag: istorichesko-sotsial'nyi aspekt, Sots. issledovaniia, 1991, 6.

Zemskov, V.N., Prinuditel'nye migratsii iz Pribaltiki v 1940-1950-kh gg., Otechestvennye arkhivy, 1993, 1, p. 4-19.

Zemskov, V.N., Politicheskie repressii v SSSR (1917-1990 gg.), Rossiia XXI, 1995a, 1-2.

Zemskov,V.N., Repatriatsiia sovetskikh grazhdan i ikh dal'neishaia sud'ba, 1944-1956 gg., Sots. issled., 1995b, 5, p. 3-12; 1995c, 6, p. 3-13. 